\title{
Penerapan Kode Etik Jurnalistik dalam Penulisan Berita Kriminal pada Media Online Infobekasi.co.id
}

\author{
Riesma Winora, Dadang Rahmat Hidayat, dan Abie Besman \\ Fakultas Ilmu Komunikasi, Universitas Padjadjaran \\ winorariesma@gmail.com
}

\begin{abstract}
This study aims to determine the application of journalistic code of ethics in the reporting process and publishing of criminal news on news website Infobekasi.co.id. In this study, researchers focused on article 3, article 4, article 5 and article 8 of the Journalistic Code of Ethics. Using a qualitative research method with a case study approach, this study is focused on examining the application of code of ethics on several aspects such as the editorial policy, news production practices from planning to the publishing of criminal news, the understanding of journalists regarding code of ethics, and analyzing 12 published criminal news content between February land March 31, 2020. The results show that Infobekasi.co.id has made efforts to implement journalistic code of ethics in order to maintain the reputation of the media, despite several aspects that are not in accordance with the code of ethics, particularly in the aspect of news writing. Researchers suggest that Infobekasi.co.id must thoroughly understand the journalistic code of ethics along with its articles in journalistic practice. Furthermore, journalists of Infobekasi.co.id must acquire a journalist competency certification to improve the quality and professionalism of journalists whose aim is to avoid misuse of the profession.
\end{abstract}

Keywords: criminal news; implementation; infobekasi; journalistic ethics code; online media

\begin{abstract}
Abstrak
Penelitian ini bertujuan untuk mengetahui bagaimana penerapan kode etik jurnalistik pada proses peliputan dan pemuatan berita kriminal pada situs berita Infobekasi. co.id. Dalam penelitian ini, peneliti memfokuskan pada penerapan pasal 3, pasal 4, pasal 5 dan pasal 8 Kode Etik Jurnalistik. Menggunakan metode penelitian kualitatif dengan pendekatan studi kasus, penelitian ini difokuskan untuk mengkaji penerapan kode etik pada beberapa aspek seperti kebijakan redaksi, praktek produksi berita dari perencanaan hingga pemuatan berita kriminal, pemahaman jurnalis tentang kode etik, hingga menganalisis 12 konten berita kriminal yang dimuat antara 1 Februari hingga 31 Maret 2020. Hasil penelitian menunjukkan bahwa Infobekasi.co.id telah melakukan upaya penerapan kode etik jurnalistik dalam rangka menjaga reputasi media, meskipun beberapa aspek tersebut tidak sesuai dengan kode etik khususnya dalam aspek penulisan berita. Peneliti menyarankan agar Infobekasi.co.id harus memahami kode etik jurnalistik beserta pasal-pasalnya dalam praktik jurnalistik. Selain itu, jurnalis Infobekasi. co.id harus memiliki sertifikasi kompetensi jurnalis untuk meningkatkan kualitas dan profesionalisme jurnalis yang bertujuan untuk menghindari penyalahgunaan profesi.
\end{abstract}

Kata kunci: berita kriminal; implementasi; infobekasi; kode etik jurnalistik; media online

\section{PENDAHULUAN}

Dalam beberapa tahun terakhir, masyarakat dikhawatirkan dengan sering terjadinya kriminalitas di berbagai daerah terutama perkotaan. Rasa takut akan tindakan kriminal dapat menimbulkan faktor negatif dan memengaruhi kehidupan serta pembangunan sosial di berbagai kota di seluruh dunia. Kriminalitas merupakan tindakan kejahatan dimana pelakunya

Korespondensi: Riesma Winora S.I.Kom., Fakultas Ilmu Komunikasi Universitas Padjadjaran, Jl.

Raya Bandung Sumedang KM. 21, Kec. Jatinangor, Kabupaten Sumedang, Jawa Barat, 45363, Email: winorariesma@gmail.com

Menyerahkan: September 2020, Diterima: Januari 2021, Terbit: Januari 2021

ISSN: 2549-0559 (cetak), ISSN: 2549-1946 (online), Website: http://jurnal.unpad.ac.id/kajian-jurnalisme 
akan dijerat dengan berbagai macam pasal dan dihukum sesuai penerapan Undang-Undang yang berlaku. Kejahatan bisa dilakukan oleh siapa saja, terlebih faktor yang melatarbelakangi seseorang melakukan tindakan kriminal karena faktor ekonomi. Tindak kriminal dapat dikelompokkan menjadi empat kelompok besar. Pertama, kejahatan terhadap benda (crimes against property). Kedua, kejahatan terhadap orang/ nyawa (crimes against a person). Ketiga, kejahatan moralitas/ tatanan sosial (morality/ social order crime) dan keempat, kejahatan berbasis teknologi (cybercrime) (Miller, 2009).

Menurut data registrasi Polri, tingkat kejahatan yang terjadi pada periode tahun 20162018 mengalami penurunan. Tingkat resiko terkena tindak kejahatan pada setiap 100 ribu penduduk mengalami penurunan, dari sekitar 140 pada tahun 2016, menjadi 129 pada tahun 2017, kemudian menurun lagi menjadi 113 pada tahun 2018 (Badan Pusat Statistik, 2019). Kendati menurun di tingkat nasional, menurut data statistik Polres Metro Bekasi pada tahun 2019 masih tercatat 228 kasus tindakan kejahatan. Sebagai rincian, kasus pencurian dengan pemberatan sepanjang 2019 terjadi sebanyak 112 kasus, sedangkan kasus penganiayaan terjadi 45 kasus dan pencurian kendaraan terjadi sebanyak 27 kasus, serta kasus pembunuhan sebanyak 2 kasus, perampokan 15 kasus, pemerkosaaan 1 kasus dan pemerasan 11 kasus.

Masyarakat masih meminati berita kriminal karena berbagai alasan. Salah satu alasan mengapa berita kriminal masih dibutuhkan karena berita kriminal dapat menjadi sumber informasi untuk meningkatkan kewaspadaan masyarakat terhadap tindakan kriminal di wilayah tempat tinggal mereka. Sayangnya, masih cukup banyak berita kriminal seperti kekerasan, pencurian, pembunuhan, sampai kejahatan asusila yang ditulis atau ditayangkan di berbagai media dengan kualitas yang kurang baik, baik dari sisi penulisan, penggunaan bahasa, pemilihan gambar yang ditayangkan, sudut pandang penceritaan, dan lain sebagainya.

Beberapa media fokus pada pemberitaan sensasional dan tidak menerapkan standar kode etik jurnalistik. Padahal, wartawan yang mengabaikan kode etik serta tidak bertanggung jawab menjadi salah satu pemicu terbentuknya konflik di Indonesia. Wartawan wajib memiliki sifat yang jujur, berpendidikan, terampil, kreatif dan berbakat. Wartawan wajib menjunjung tinggi kebenaran dan harus selalu tanggap, juga kritis terhadap situasi dan kondisi agar bisa membedakan antara berita dan opini karena sejatinya wartawan tidak boleh memasukkan opini maupun argumen dalam penulisan berita, karena itu sangat melanggar dan merugikan banyak pihak. Berita yang layak disajikan untuk publik memiliki aspek serta kriteria yang terdalam dalam nilai-nilai berita karena tidak semua berita layak dimuat (Wahyudi, 1991).

Di Indonesia, kode etik terutama yang berkaitan dengan kegiatan jurnalistik ada beberapa jenis seperti Kode Etik Aliansi Jurnalistik Independen (AJI), Kode Etik Persatuan Wartawan Indonesia (PWI), serta Kode Etik Wartawan Indonesia (KEWI). Beberapa kode etik tersebut kemudian disatukan, ditetapkan, disepakati bersama, serta disahkan oleh Dewan Pers. Kode etik jurnalistik ditetapkan melalui Peraturan Dewan Pers Nomor 6/Peraturan-DP/'V/2008 Tentang Pengesahan Surat Keputusan Dewan Pers Nomor 03/SK-DP/III/2006 Tentang Kode Etik Jurnalistik sebagai Peraturan Dewan Pers (DewanPers, 2013).

Dari beberapa media lokal online di Bekasi, peneliti memilih media online Infobekasi. co.id dalam penelitian ini karena dua sisi pertimbangan, yaitu sisi peliputan dan pemuatan berita; serta sisi akses atau kunjungan pembaca. Dari sisi peliputan dan pemuatan berita, Infobekasi.co.id memiliki jangkauan liputan di daerah kota Bekasi maupun kabupaten Bekasi. Dalam proses pengolahan berita, wartawan Info Bekasi terjun langsung ke lapangan untuk meliput berita. Hal ini dibuktikan dengan pengambilan gambar yang diberi watermark serta sumber berita yang jelas. Sementara dari sisi kunjungan pembaca, Info Bekasi merupakan media yang banyak dikunjungi masyarakat khususnya warga Bekasi. Info Bekasi cukup 
rutin memberitakan berita kriminal yang didominasi oleh berita-berita tentang pencurian dan kekerasan. Berdasarkan hasil pengamatan, secara keseluruhan Info Bekasi memproduksi 130-150 berita. Sekitar 40\% diantaranya adalah berita kriminal. Dilihat dari Google Analytic, Info Bekasi rata-rata dikunjungi oleh lebih dari 20.000 ribu visitor per hari dengan rata-rata pageview atau kunjungan halaman lebih dari 50.000 per hari. Tidak hanya itu, Info Bekasi juga diikuti oleh lebih dari 48.000 facebooker yang memungkinkan Info Bekasi mengirim tautan iklan ke dalam website pengiklanan. Infobekasi.co.id juga mengelola kanal media sosial seperti Youtube, Instagram, Twitter, FanPage dan Facebook.

Pada periode 01 Februari hingga 31 Maret 2020, terdapat 20 berita kriminal. Di antara 20 berita tersebut, 12 berita (57,14\%) merupakan berita pencurian dan kekerasan, sedangkan 9 lainnya (42,85\%) adalah berita pembunuhan dan kejahatan asusila. Data tersebut menunjukkan bahwa pada periode Februari hingga Maret 2020 terdapat lebih banyak tindak kejahatan kekerasan dan pencurian yang dimuat pada Infobekasi.co.id. Dari 20 berita tersebut, penelitian difokuskan pada 12 berita kriminal yang lebih banyak terjadi yaitu pencurian dan kekerasan.

Penelitian ini akan menelusuri tiga aspek dalam "Penerapan Kode Etik Jurnalistik dalam Penulisan Berita Kriminal pada Media Online Infobekasi.co.id", yaitu: a) Pengetahuan dan Pemahaman Wartawan Infobekasi.co.id Terhadap Kode Etik Jurnalistik; b) Manajemen Redaksi yang Dijalankan Media Online Infobekasi.co.id; serta c) Praktik Penerapan Kode Etik Jurnalistik pada Infobekasi.co.id.

Pengetahuan dan pemahaman wartawan kode etik jurnalistik khususnya terhadap pasal 3 , 4, 5 dan 8 diharapkan dapat menggambarkan apakah pengetahuan dan pemahaman mengenai kode etik ini mendasari proses kerja wartawan dan menajeman redaksi yang dijalankan Infobekasi.co.id dalam meliput dan memuat atau menayangkan berita kriminal. Pasal 3 menyebutkan, "Wartawan Indonesia selalu menguji informasi, memberitakan secara berimbang, tidak mencampurkan fakta dan opini yang menghakimi, serta menerapkan asas praduga tak bersalah". Pasal 4 menyebutkan bahwa "Wartawan Indonesia tidak membuat berita bohong, fitnah, sadis dan cabul". Pasal 5 menyebutkan bahwa "Wartawan Indonesia tidak menyebutkan dan menyiarkan identitas korban kejahatan asusila dan tidak menyebutkan identitas anak yang menjadi pelaku kejahatan". Sedangkan pasal 8 menyebutkan bahwa "Wartawan Indonesia tidak menulis atau menyiarkan berita berdasarkan prasangka atau diskriminasi terhadap seseorang atas dasar perbedaan suku, ras, warna kulit, agama, jenis kelamin dan bahasa, serta tidak merendahkan martabat orang lemah, miskin, sakit, cacat, jiwa, atau jasmani” (DewanPers, 2013).

Kode etik jurnalistik merupakan rambu-rambu sekaligus perlindungan bagi wartawan dalam menjalankan profesi dan kegiatannya. Namun dalam pelaksanaannya, pengetahuan dan pemahaman wartawan terhadap kode etik sangatlah beragam. Di sisi lain, kendati mengetahui kode etik, tidak semua wartawan melaksanakan kode etik karena berbagai keadaan. Pada sebuah penelitian mengenai wartawan media cetak bertema Islam di Jakarta, diketahui bahwa pemahaman wartawan akan kode etik jurnalistik cukup tinggi. Di sisi lain, penelitian ini menyebutkan juga bahwa kendati dedikasi merupakan dimensi terpenting dalam kinerja wartawan di lapangan, hubungan antara pemahaman kode etik jurnalistik dengan profesionalisme, dedikasi dan keahlian wartawan sangat lemah (Prisgunanto, 2017).

Pelanggaran kode etik yang lazim terjadi adalah praktik suap. Praktik ini terjadi karena rendahnya komitmen individual dan persepsi yang salah dari individu jurnalis soal praktik suap. Latar belakang individu jurnalis juga memengaruhi pemahaman mereka terhadap profesi jurnalis serta kode etik yang harus dijalankan (Pramesti, 2014). Selain praktik suap, pelanggaran kode etik juga pernah diteliti adalah terkait pasal 3 Kode Etik Jurnalistik yaitu 
wartawan tidak menguji informasi (Maheni, Dewi, \& Haryani, 2017). Kemungkinan terjadi atau tidaknya pelanggaran kode etik juga terkait mekanisme pengelolaan redaksi. Pemberitaan atas sebuah isu yang direncanakan dengan baik akan memberi kontribusi pada proses peliputan dan pemuatan berita yang memenuhi kode etik (Gawi, Aminulloh, \& Yasak, 2017).

Penelitian ini menggunakan teori Hierarchy of Influence atau hirarki pengaruh dengan tujuan untuk mengetahui faktor-faktor internal maupun eksternal redaksi maupun media Infobekasi.co.id yang memengaruhi konten berita kriminal Infobekasi.co.id. Pamela J. Shoemaker dan Stephen D. Reese membagi teori hirarki pengaruh menjadi lima tingkatan yang memiliki pengaruh terhadap isi konten media dan kebijakan redaksi dalam proses pemberitaan. Lima tingkatan tersebut yaitu level individu, level rutinitas media, level organisasi, level ekstramedia dan level ideologi (Shoemaker \& Reese, 1996).

\section{METODE}

Penelitian ini menggunakan pendekatan deskriptif kualitatif dengan paradigma konstruktivis. Paradigma konstruktivisme dirasa cocok digunakan dalam penelitian ini karena dapat menganalisis socially meaningful action atau makna dari praktik-praktik sosial secara terstuktur dan sistematis. Penelitian ini dapat ditempuh dengan cara melakukan pengamatan langsung ke lapangan secara rinci terhadap pihak-pihak yang terkait di Infobekasi.co.id. Pengamatan ini berfungsi untuk membantu peneliti dalam memahami dan menafsirkan bagaimana pihak Infobekasi.co.id bekerja dalam mengelola berita.

Penelitian kualitatif digunakan untuk mencapai pemahaman mendalam mengenai sebuah organisasi atau suatu peristiwa khusus daripada mendeskripsikan permukaan sampel besar dari populasi (Herdiansyah, 2010). Penelitian ini dimaksudkan untuk mengungkap data dan informasi terkait penerapan kode etik jurnalistik di media online Infobekasi.co.id, kemudian data tersebut mampu mendeskripsikan keadaan yang sesungguhnya yang terjadi di lapangan secara mendalam dan terstruktur.

Yin (1996) menjelaskan bahwa studi kasus merupakan salah satu cara pendekatan pada riset ilmu-ilmu sosial, dimana secara umum pendekatan tersebut lebih sesuai jika pokok persoalan suatu riset berkenaan dengan "bagaimana" atau "mengapa". Penelitian ini memfokuskan pada satu objek tertentu secara intensif dan rinci yang bertujuan untuk mengamati dan menganalisis masalah secara cermat dan tuntas dengan studi kasusnya yaitu berita kriminal pencurian dan kekerasan. Penelitian ini bertujuan melihat bagaimana praktik kode etik jurnalistik dalam pasal 3, 4, 5 dan 8 secara mendalam dan sistematis.

Teknik pengumpulan data yang digunakan oleh peneliti dibagi menjadi tiga tahap yaitu observasi, wawancara, dan penggalian data dari dokumen. Observasi dilakukan terhadap proses produksi berita serta rangkaian berita kriminal yang tampil pada situs Infobekasi. co.id. Wawancara dilakukan terhadap empat orang dari tim redaksi dari mulai pimpinan redaksi hingga reporter. Sedangkan, teknik analisis dan penyajian data yang digunakan adalah Miles dan Huberman yang memiliki empat tahap yaitu (1) pengumpulan data, (2) reduksi data, (3) penyajian data, dan (4) simpulan dan verifikasi (Miles \& Huberman, 1992). Teknik triangulasi digunakan untuk membandingkan hasil pengamatan dengan hasil wawancara dan membandingkan hasil wawancara dengan isi suatu dokumen.

\section{HASIL DAN PEMBAHASAN}

\section{Pengetahuan dan Pemahaman Wartawan terhadap Kode Etik Jurnalistik}

Berdasarkan penelusuran penggalian data, tiga orang informan mengaku paham secara garis besar kode etik jurnalistik, karena kode etik merupakan sebuah pedoman yang harus ditaati 
oleh seorang wartawan serta merupakan acuan untuk para jurnalis membuat berita Seorang informan reporter Info Bekasi menjelaskan bahwa faktor yang memengaruhi pelanggaran kode etik jurnalistik ialah pemahaman. Jika wartawan tidak paham terhadap kode etik jurnalistik, maka potensi melanggarnya sangat tinggi.

"Menurut saya, KEJ bukan hanya dipahami saja tetapi juga harus diterapkan oleh seluruh wartawan dan ini mutlak. Karena menaati KEJ adalah rambu-rambu dalam bekerja. KEJ juga merupakan pelindung bagi pekerja profesional yang mendorong persaingan sehat antar praktisi dan melindungi masyarakat dari malpraktik oleh praktisi yang kurang professional." (Informan Penelitian, 2020)

Informan lain mengingatkan tentang pentingnya menguji informasi (pasal 3 kode etik jurnalistik). Menurut informan tersebut, sebelum paham untuk menulis berita, wartawan juga harus melakukan validasi data karena informasi yang mengalir dari masyarakat belum tentu sama dengan hasil di lapangan.

Seorang informan lain menyebutkan, bagi wartawan yang berfokus di bidang kriminalitas, kode etik jurnalistik adalah acuan dalam menulis berita. Menurutnya, di era sekarang banyak sekali masyarakat Indonesia yang langsung membagikan informasi tanpa mengolah terlebih dahulu informasi yang diperolehnya. Akibatnya berita hoax atau bohong rentan tersebar. Disiplin dalam melakukan check dan recheck adalah kunci dalam penerapan kode etik jurnalistik.

"Biasanya faktor utamanya adalah melakukan check and recheck saat mendapatkan informasi, karena saat ini semakin cepatnya informasi yang mengalir dari masyarakat melalui media sosial membuat wartawan sering 'tergoda' dengan informasi tersebut dan langsung dibuat berita saja padahal itu tidak valid. Malasnya wartawan melakukan validasi data. Banyaknya kepentingan dari pihak pemilik media yang mengharuskan wartawan mengikuti kepentingan perusahaan." (Informan Penelitian, 2020)

Hal tersebut membuat sang informan mengaku dirinya sebagai wartawan harus paham terhadap kode etik serta pasal yang terkandung di dalamnya karena wartawan bertugas menyajikan informasi yang akurat untuk masyarakat dan meminimalisir terjadinya berita bohong dan melanggar pasal kode etik jurnalistik. Seorang wartawan tetap harus memiliki prinsip untuk mematuhi kode etik jurnalistik karena walaupun wartawan memiliki kebebasan yang disebut kebebasan pers, yakni kebebasan mencari, memperoleh, dan menyebarluaskan gagasan dan informasi; UU No. 40 Tahun 1999 tentang Pers menyebutkan, kemerdekaan pers dijamin sebagai hak asasi warga negara, bahkan pers nasional tidak dikenakan penyensoran, pembredelan, atau pelanggaran penyiaran.

Wartawan Info Bekasi mengikuti pelatihan jurnalistik yang diadakan oleh Tempo Institute. Wartawan Info Bekasi sendiri belum pernah melakukan pelatihan jurnalistik secara mandiri. Pelatihan jurnalistik yang diikuti yaitu Uji Kompetensi Wartawan (UKW) dan pelatihan dasar penelitian berita sesuai KEJ. Menurut penjelasan Adi Nugroho selaku Pemimpin Redaksi Infobekasi.co.id, seluruh wartawan Info Bekasi tidak masuk ke dalam organisasi kewartawanan. Saat penelitian ini disusun, Info Bekasi sedang dalam proses pendataan media agar terverifikasi oleh Dewan Pers. Menurut Dewan Pers, pada umumnya wartawan harus sudah tergabung kedalam organisasi wartawan yang diakui oleh Dewan Pers seperti Aliansi Jurnalis Independen (AJI), Ikatan Jurnalis Televisi Indonesia (IJTI), atau Persatuan Wartawan Indonesia (PWI). Meski belum tergabung, menurut penuturan pemimpin redaksinya, wartawan Info Bekasi sangat menjaga citra baik media online Info Bekasi, karena Info Bekasi merupakan salah satu media online lokal yang cukup dikenal warga Bekasi. Wartawan Infobekasi.co.id pun memiliki latar belakang disiplin ilmu yang beragam. Menurut pemimpin redaksi, untuk menjaga reputasi dan meningkatkan kualitas, Info Bekasi memfasilitasi wartawannya untuk mengikuti pelatihan jurnalistik. 
170 | Kajian Jurnalisme

Volume 04 Nomor 02 Tahun 2021

DOI: $10.24198 /$ jkj.v4i2.29323

\section{Pengelolaan Manajemen Redaksional yang Dijalankan Media Online Infobekasi.co.id}

Manajemen redaksional merupakan elemen yang sangat penting dan dibutuhkan dalam setiap perusahaan media, karena dengan adanya manajemen yang baik maka tujuan perusahaan akan tercapai. Terdapat empat tahapan yaitu tahap perencanaan, tahap pengorganisasian, tahap pelaksanaan, dan tahap pengawasan.

Bagan 1 Tahapan Manajemen Redaksional

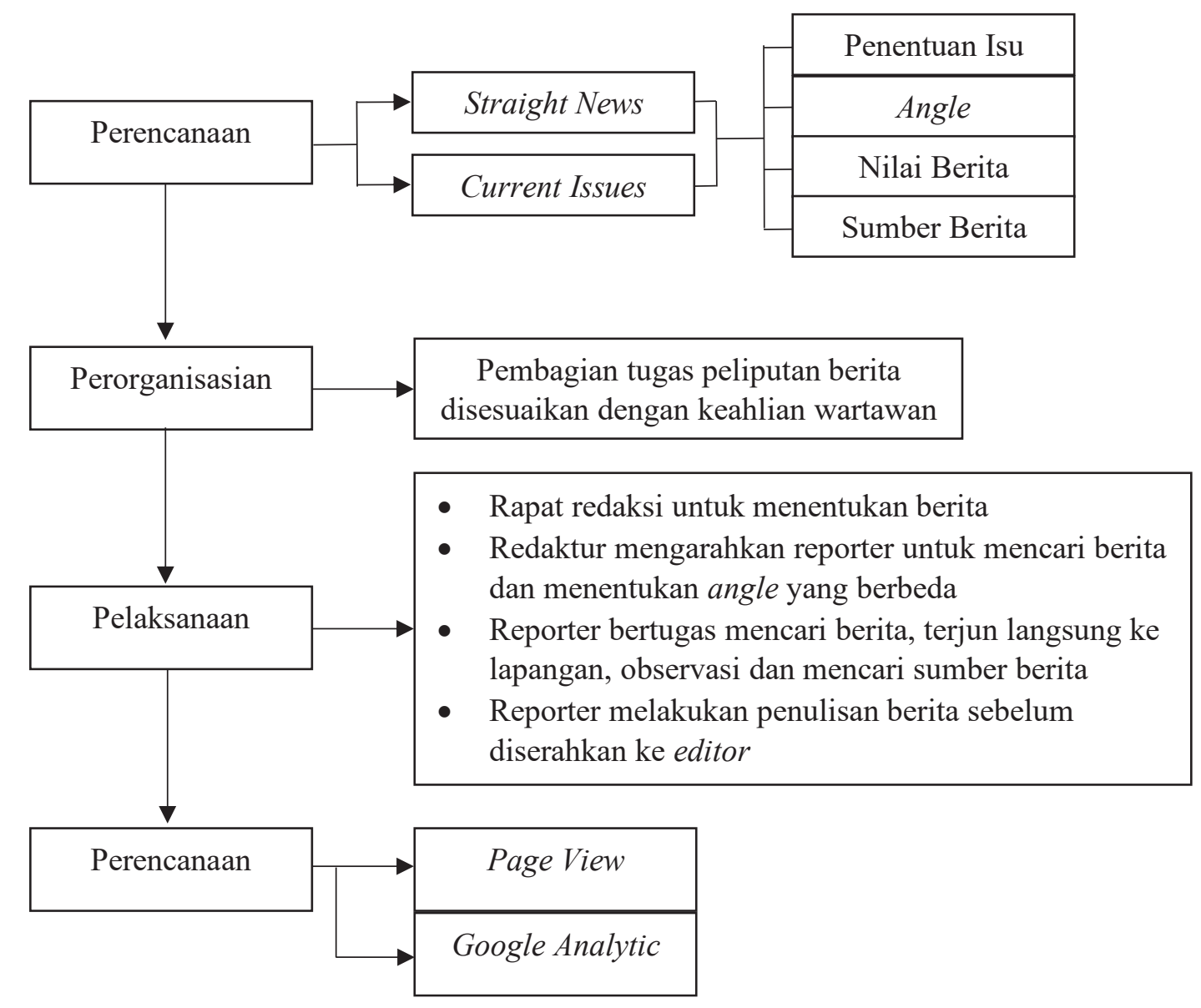

Sumber: Rekonstruksi Peneliti

\section{Perencanaan}

Pada tahap perencanaan dalam menentukan berita, Info Bekasi menjalankan rapat redaksi rutin seminggu sekali jika ada 'kasus pendalaman'. Rapat perencanaan ini dibuat dan dilaksanakan secara rutin untuk saling bertukar ide dan mengumpulkan berita-berita yang menarik untuk dimuat di Infobekasi.co.id. Selanjutnya, perencanaan tersebut harus disusun dengan baik sebagai panduan bagi wartawan atau reporter yang menjalankan tugasnya di lapangan. Selebihnya, jika tidak ada pembahasan lebih lanjut, diskusi dilakukan melalui aplikasi percakapan whatsapp. Info Bekasi menerapkan kerjasama tim dan selalu menjaga komunikasi antar tim walaupun tidak selalu datang ke kantor. Peraturan yang dimiliki oleh Info Bekasi adalah saling membantu ketika salah satu pekerjanya merasa sulit. Terkadang ketika salah satu anggota tim Info Bekasi baik wartawan ataupun bukan wartawan sedang berpergian keluar dan menemukan peristiwa yang menarik, anggota tim tersebut langsung menyampaikan informasi tersebut kepada tim redaksi. Wartawan Info Bekasi biasanya kemudian langsung menyusunkan beritanya dan mempublikasikannya melalui website Infobekasi.co.id. 
Volume 04 Nomor 02 Tahun 2021

DOI: $10.24198 /$ jkj.v4i2.29323

\section{Pengorganisasian}

Sejak awal berdirinya, Info Bekasi sudah menetapkan penyusunan struktur organisasi dan pembagian tugas. Manajemen redaksional dibagi menjadi empat tingkatan, yaitu Pemimpin Redaksi, Redaktur Pelaksana, Redaktur dan Wartawan. Redaktur Info Bekasi kemudian memberikan penugasan sesuai dengan keahlian wartawan.

Info Bekasi memiliki empat reporter masing-masing memiliki keahlian yang berbeda. Dua orang ditugaskan pada bidang penulisan berita kriminal, satu orang pada bidang penulisan berita publik dan kependudukan. Satu orang lainnya ditugaskan pada bidang perkotaan dan olahraga. Sedikitnya jumlah anggota redaksi membuat beberapa orang memiliki rangkap jabatan. Pemimpin redaksi juga merangkap jabatan sebagai redaktur dan reporter. Seorang redaktur lainnya juga merangkap menjadi reporter.

Peraturan Dewan Pers Nomor: 03/ Peraturan-DP/X/2019 tentang Standar Perusahaan Pers pasal 8 menegaskan bahwa penanggung jawab redaksi atau pemimpin redaksi wajib memiliki kompetensi wartawan utama. Pasal 9 berbunyi, wartawan utama dapat menjadi penanggung jawab redaksi atau pemimpin redaksi maksimal pada 2 (dua) media. Menurut Ketua Komisi Pendidikan, Pelatihan dan Pengembangan Profesi Dewan Pers Jamalul Insan, salah satu syarat menjadi penanggung jawab redaksi haruslah mempunyai sertifikasi wartawan utama. Sementara itu, Ketua Komisi Pemberdayaan Organisasi Dewan Pers Asep Setiawan menyatakan sebuah media yang mempublikasikan karya jurnalistik harus terverifikasi di Dewan Pers. Media tersebut harus memiliki struktur organisasi yang jelas karena menjalankan profesi yang nilai utamanya adalah integritas.

Saat penelitian ini dilakukan, pemimpin redaksi Info Bekasi belum memiliki sertifikat sebagai wartawan utama. Kendati demikian, Info Bekasi menyatakan sedang dalam proses pendataan media agar terverifikasi oleh Dewan Pers. Selain itu Info Bekasi mengaku selalu berupaya meningkatkan kompetensi wartawannya dengan mengikutsertakannya pada pelatihan yang diselenggarakan oleh media massa bereputasi seperti Tempo.

\section{Pelaksanaan}

Info Bekasi memiliki tim untuk menjalankan tugas sesuai bidang masing-masing. Proses pada tahap ini meliputi pengolahan materi awal berita, peliputan berita, penelitian berita, sampai penyuntingan atau editing naskah berita. Info Bekasi mengaku memahami betul bagaimana proses editing berita yang dimuat Infobekasi.co.id. Jenis berita yang dimuat oleh Info Bekasi bersifat soft news berisi berita kriminal, perkotaan, dan berita publik. Untuk memperoleh berita tersebut, wartawan Info Bekasi terjun langsung ke lapangan untuk meliput, agar bisa mendeskripsikan secara langsung suatu peristiwa yang terjadi di lokasi.

Info Bekasi menerapkan proses pemberitaan yang terstruktur. Sebuah tema fakta atau peristiwa dapat dikembangkan menjadi lebih dari satu berita. Sebagai contoh, sebuah kasus kekerasan dapat dikembangkan menjadi dua atau tiga berita. Berita pertama memuat tentang apa yang sedang terjadi, berita kedua menjelaskan tentang kronologi kasusnya, berita ketiga memuat informasi akhir dari kasus tersebut. Pemecahan berita ini juga menjadi mekanisme pemuatan berita melalui sudut pandang yang berbeda. Pada tahap ini terjadi proses cover both sides.

\section{Pengawasan}

Info Bekasi melakukan pengawasan output dan input setiap harinya terhadap proses editing, produksi, dan pemuatan berita. Menurut informan, pengawasan ini dilakukan agar Info Bekasi terus berkembang menjadi media online yang dipercaya masyarakat dan terus belajar 
172 | Kajian Jurnalisme

Volume 04 Nomor 02 Tahun 2021

DOI: $10.24198 /$ jkj.v4i2.29323

terhadap berbagai kritikan yang datang dari masyarakat. Evaluasi dilakukan terhadap jumlah pembaca berita per hari, bentuk komentar dari masyarakat, penjualan iklan dari berbagai platform, serta perkembangan perusahaan media secara keseluruhan. Info Bekasi memiliki pengawasan dua arah. Pengawasan internal dipimpin oleh Pemimpin Redaksi, sedangkan eksternal dilakukan dengan mengamati Pageview dan Google Analytic.

\section{Praktik Penerapan Kode Etik Jurnalistik Pasal 3, 4, 5 dan 8}

Bagian ini mengkaji kesesuaian praktik penerapan kode etik jurnalistik, khususnya terkait pasal 3, 4, 5, dan 8; yang dijalankan Info Bekasi untuk penulisan berita kriminal. Untuk menjamin kemerdekaan pers dan hak publik yang bertujuan untuk memperoleh informasi yang benar, akurat dan berimbang, wartawan Indonesia memerlukan landasan moral dan etika profesi kewartawanan sebagai pedoman operasional demi menjaga kepercayaan publik. Untuk itu wartawan Indonesia harus menaati kode etik jurnalistik yang berlaku.

Penelitian ini juga menganalisis isi berita kriminal yang dimuat oleh Info Bekasi. Analisis terhadap isi berita dilakukan untuk melihat bagaimana pilihan kosa kata dan sikap yang digunakan oleh media online Infobekasi.co.id dalam menyajikan berita kriminal khususnya kekerasan dan pencurian, pada periode 1 Februari sampai dengan 31 Maret 2020. Karena jumlah berita yang diterbitkan atau dimuat Info Bekasi setiap hari tidak sama, analisis dilakukan terhadap satu berita per hari.

Media cetak biasanya memuat sebuah berita secara berimbang. Pada media online atau daring, prinsip keberimbangan berita tidak muncul dalam satu berita, tapi dalam prinsip update berita, sepotong-sepotong, atau dipecah-pecah. Dengan demikian, keberimbangan biasanya muncul pada berita kedua, ketiga dan selanjutnya. Praktik ini mengandung potensi persoalan. Persoalan muncul pada berita-berita pertama yang bersifat tendensius, mengarahkan pembentukan opini publik yang berpotensi merugikan pihak tertentu. Pihak yang 'disudutkan' merasa tidak mendapat kesempatan berikutnya. Kesempatan untuk klarifikasi pun sering dirasakan terlambat. Atas masalah ini, media online sering dituding membuat berita yang tidak berimbang (Margianto \& Saefullah, 2012).

Tabel berikut ini memuat rekapitulasi berita kriminal pada periode yang diteliti berdasarkan topik pemberitaan.

Tabel 1. Rekapitulasi Berita Kriminal Pencurian dan Kekerasan Edisi 1 Februari - 31 Maret 2020

\begin{tabular}{|c|l|c|c|c|}
\hline \multirow{2}{*}{ No } & \multirow{2}{*}{ Kategori } & \multicolumn{2}{|c|}{ Berita Kriminal } & \multirow{2}{*}{ Jumlah } \\
\cline { 3 - 4 } & & Pencurian & Kekerasan & 8 \\
\hline 1 & Berimbang & 5 & 3 & 0 \\
\hline 2 & Bohong & 0 & 0 & 4 \\
\hline 3 & Fitnah & 3 & 1 & 11 \\
\hline 4 & Sadis & 3 & 8 & 0 \\
\hline 5 & Cabul & 0 & 0 & 0 \\
\hline 6 & Prasangka & 0 & 0 & 12 \\
\hline 7 & Identitas & 3 & 9 & $\mathbf{3 5}$ \\
\hline \multicolumn{2}{|l}{ Total } & $\mathbf{1 4}$ & $\mathbf{2 1}$ & \\
\hline
\end{tabular}

Sumber: diolah dari: Riesma Winora (2020)

Analisis diarahkan untuk menguji keberimbangan berita, kebenaran fakta (ada tidaknya kebohongan), fitnah, sadis, cabul, prasangka, serta penyebutan identitas (yang harus disebutkan 
maupun tidak disebutkan). Penelitian ini menemukan terdapat berita yang tidak berimbang karena tidak adanya pernyataan dari saksi maupun pelaku yang membenarkan persitiwa tersebut, pelaku tidak diberikan hak jawab terkait peristiwa yang diberitakan, penggunaan kata-kata sadis, penyebutan identitas yang sepatutnya dirahasiakan karena alasan keamanan sumber berita, serta sumber berita yang tidak jelas. Sebagai contoh, pada berita edisi Senin 2 Februari 2020, yang berjudul "Begal Sadis di Tambun Terpaksa Ditembak Polisi" terdapat kata-kata sadis seperti menyebutkan "membacok korban bertubi-tubi hingga tak berdaya"; terdapat penyebutan nama korban tindak kriminal yang dapat memberi resiko pada diri korban. Pada berita lain, seperti berita edisi 07 Februari 2020 yang berjudul "Maling Motor Bonyok Dipukuli Massa di Margahayu" isi berita tidak mencantumkan sumber berita yang jelas, hanya mencantumkan kalimat "informasi yang berhasil dirangkum Infobekasi.co.id" serta mencantumkan foto pelaku yang berlumuran darah. Hal lain yang juga terjadi adalah deskripsi kejadian tindak kriminal bersumber dari pihak ketiga, bukan dari pelaku atau korban. Deskripsi ini terkait dengan akurasi informasi serta kewajiban wartawan untuk menguji setiap informasi yang diperolehnya.

\section{Hirarki Pengaruh Terhadap Redaksi dan Penerapan Kode Etik pada Info Bekasi}

Penerapan kode etik jurnalistik pasal 3, 4, 5 dan 8 dalam penulisan berita kriminal yang dimuat oleh Info Bekasi tentunya dipengaruhi oleh faktor internal maupun eksternal media. Pengaruh internal terjadi pada proses produksi berita terjadi melalui mekanisme pengawasan oleh tim redaksi agar sebuah berita layak dimuat dan mudah dipahami pembaca. Faktor eksternal adalah masyarakat itu sendiri yang dapat menilai langsung kuantitas serta kualitas berita Info Bekasi. Untuk menampung aspirasi pembaca, Info Bekasi menyajikan wadah kritik dan saran pada setiap artikel berita.

Lebih lanjut, Pamela J. Shoemaker dan Stephen D Reese membagi pengaruh-pengaruh yang ada dalam teorinya menjadi lima level yaitu individu pekerja media, rutinitas media, organisasi media, dan ideologi. Shoemaker dan Reese memiliki pandangan bahwa media bukan hanya medium pasif (media as channels), melainkan media memiliki peran aktif dalam membentuk realitas (media as participants).

\section{Level Individu}

Level individu (pekerja) dalam sebuah media dapat memengaruhi isi berita dari media tersebut. Latar belakang pendidikan wartawan memang tidak memiliki pengaruh secara langsung terhadap isi media; namun karakter individu wartawan seperti sikap, perilaku, personal maupun profesionalitasnya dapat memberikan pengaruh terhadap konten media. Info Bekasi memiliki pekerja dengan latar belakang pendidikan, usia, jenis kelamin yang berbeda-beda. Kondisi ini menyebabkan Info Bekasi dapat menerapkan pembagian tugas terhadap wartawan berdasarkan kesesuaian pendidikan, pengalaman, serta keahlian wartawan, seperti misalnya menempatkan berita olah raga pada wartawan yang memiliki bekal pendidikan atau pengalaman di bidang itu. Namun di sisi lain, karena tidak semua wartawan Info Bekasi memperoleh pendidikan Ilmu Komunikasi atau Ilmu Jurnalistik, yang memang khusus mempelajari pengelolaan berita dan media; seperti diakui informan, kondisi ini sedikit banyak menyebabkan kesulitan ketika informan harus menulis berita secara menarik dan sesuai dengan kaidah penulisan serta kode etik jurnalistik.

\section{Level Rutinitas Media}

Unsur khalayak sangat berpengaruh pada level ini karena pada dasarnya berita disajikan untuk masyarakat, media harus bisa menyesuaikan berita-berita yang dibutuhkan masyarakat. 
174 | Kajian Jurnalisme

Volume 04 Nomor 02 Tahun 2021

DOI: $10.24198 /$ jkj.v4i2.29323

Secara konseptual, dapat dianalisis bahwa Info Bekasi telah menerapkan rutinitas media berdasarkan empat tahap manajemen redaksional yaitu perencanaan, pengorganisasian, pelaksanaan serta pengawasan yang sudah peneliti uraikan sebelumnya. Berita yang baik adalah berita yang mempunyai nilai aktual, faktual, kedekatan, keunikan, menyentuh kemanusiaan dan kontroversi. Info Bekasi berupaya mengaktualisasikan nilai-nilai tersebut.

Dalam memproduksi berita, Info Bekasi berupaya untuk menerapkan keteraturan dalam pengelolaan media (rutinitas media). Karena berita yang disajikan seputar wilayah bekasi, masyarakat pun merasa terpenuhi akan informasi yang disajikan misalnya tentang kasus pencurian dan kekerasan yang marak di daerah Bekasi sehingga masyarakat juga bisa mengantisipasi untuk kejadian tersebut. Berita yang didapatkan tidak hanya bersumber dan ditulis oleh wartawan, tetapi Info Bekasi juga menggabungkan kekuatan jurnalisme warga dalam membantu media ini. Menurut Info Bekasi, peristiwa terjadi setiap hari dan belum tentu wartawan meliput secara cepat kejadian tersebut sehingga perlu menggabungkannya dengan konsep dan praktik jurnalisme warga agar berbagai informasi penting dan menarik yang tidak dapat diliput wartawan Info Bekasi tetap dapat disampaikan dengan baik kepada khalayak. Penuturan dari jurnalis warga juga seringkali lebih mudah dipahami oleh sesama masyarakat awam.

\section{Level Organisasi Media}

Level organisasi media lebih berpengaruh dibandingkan level individu dan level rutinitas media karena level ini berbicara tentang kepemilikan media yang berkaitan dengan struktur manajemen organisasi, kebijakan dan tujuan media. Pada Info Bekasi, kebijakan dipegang oleh pemilik media yaitu Adi Nugroho. Pimpinan atau pemilik media berperan dalam menentukan apakah sebuah berita layak untuk naik atau tidak. Struktur tertinggi dari manajemen media biasanya adalah pemilik media. Tidak hanya itu, media tentunya akan lebih aman jika tidak memberitakan buruk mengenai sebuah partai politik jika pemilik media mempunyai keterkaitan terhadap partai politik tersebut. Info Bekasi adalah perusahaan media yang dipimpin oleh Deni Ardini dan bernaung di bawah badan hukum PT. Asyik Media Group. Adapun visi yang dimiliki Info Bekasi yaitu "Info Bekasi mengusung gagasan baru dalam khasanah dunia jurnalistik yaitu Good New is Good News. Meninggalkan dogma lama Bad News Is Good News". Sedangkan misinya "Good News is Good News, kami hadir bukan untuk menghakimi tapi kami hadir untuk mencerahkan dan memberikan perspektif yang lebih luas".

Pada kasus Info Bekasi, keputusan untuk memuat pemberitaan kriminal, perkotaan atau publik, olahraga, lifestyle dan sejarah diambil berdasarkan kesepakatan bersama melalui rapat redaksi yang dilakukan seminggu sekali secara tatap muka dan melalui chatting group ketika tidak adanya pertemuan.

\section{Level Ekstramedia}

Pemberitaan Info Bekasi yang kebanyakan bermuatan berita kriminal dipengaruhi oleh khalayaknya yang berasal dari wilayah Bekasi. Info Bekasi menekankan nilai kedekatan dengan hanya membuat berita dan tayangan seputar peristiwa yang terjadi di daerah Bekasi, Jawa Barat. Oleh karena itu, sumber berita atau narasumber pun hampir semua berasal dari masyarakat Bekasi. Pemasang iklan pada Info Bekasi sebagian besar juga berasal dari Bekasi, seperti media partner untuk kegiatan sekolah, universitas, komunitas serta iklan produk yang akan dimuat melalui berbagai platform yang dimiliki Info Bekasi. Manajemen Info Bekasi mengaku kondisi ini cukup bagi Info Bekasi untuk mencapai pasarnya. 
Volume 04 Nomor 02 Tahun 2021

DOI: $10.24198 /$ jkj.v4i2.29323

\section{Level Ideologi Media}

Level ideologi media dipandang sebagai kerangka berpikir tertentu yang dipakai individu untuk melihat realitas dan bagaimana menghadapinya. Level ini berbicara tentang ide atau gagasan yang dimiliki oleh perusahaan media. Level ini bersifat abstrak sehingga tidak disadari oleh banyak khalayak. Tujuan utama Info Bekasi adalah hanya untuk meliterasi masyarakat Bekasi agar tidak menelan informasi secara mentah-mentah. Info Bekasi percaya bahwa pekerja medianya memberikan informasi yang benar, aktual serta faktual untuk disampaikan kepada masyarakat. Dapat terlihat bahwa ideologi media ini cukup berpengaruh kepada pemberitaan Info Bekasi yang berupaya mengedepankan standar jurnalistik dan lebih memahami apa yang menjadi kebutuhan masyarakat Bekasi.

\section{SIMPULAN}

Berdasarkan penelusuran dalam penelitian ini, dapat disimpulkan bahwa wartawan Info Bekasi mengaku secara garis besar memahami kode etik jurnalistik, namun tidak terlalu paham akan uraian dari dari pasal-pasal yang terkandung di dalam kode etik jurnalistik. Untuk menjaga kualitas dan etika pemberitaan, manajemen redaksional menjalankan empat tahap pada pengelolaan atau produksi berita kriminal, yaitu tahap perencanaan, pengorganisasian, pelaksanaan dan pengawasan. Namun pada praktiknya, berdasarkan analisis terhadap isi berita ditemukan bahwa masih terjadi persoalan pada sebagian berita kriminal menyangkut aspek keberimbangan berita, kebenaran fakta (ada tidaknya kebohongan), fitnah, sadis, cabul, prasangka, serta penyebutan identitas (yang harus disebutkan maupun tidak disebutkan). Penelitian ini menemukan terdapat berita yang tidak berimbang karena tidak adanya pernyataan dari saksi maupun pelaku yang membenarkan peristiwa tersebut, pelaku tidak diberikan hak jawab terkait peristiwa yang diberitakan, penggunaan kata-kata sadis, penyebutan identitas yang sepatutnya dirahasiakan karena alasan keamanan sumber berita, serta sumber berita yang tidak jelas. Kondisi ini menjadi catatan penting terhadap aspek kemampuan wartawan untuk menerapkan pengetahuan mengenai kode etik jurnalistik ke dalam praktik kerjanya sehari-hari.

\section{DAFTAR PUSTAKA}

Badan Pusat Statistik. (2019). Statistik Kriminal 2019. Badan Pusat Statistik, 1-218.

DewanPers. (2013). Pers Berkualitas Masyarakat Cerdas. (B. Nugroho \& Samsuri, Eds.). Jakarta: Dewan Pers.

Gawi, G., Aminulloh, A., \& Yasak, E. M. (2017). Penerapan Kode Etik Jurnalistik Dalam Surat Kabar Harian Surya Malang. Jurnal Ilmu Sosial Dan Ilmu Politik, 6(1), 19-27. Diakses dari https://publikasi.unitri.ac.id/index.php/fisip/article/view/366

Herdiansyah, H. (2010). Metodologi Penelitian Kualitatif: Untuk Ilmu-ilmu Sosial. Jakarta: Salemba Empat.

Maheni, M. T., Dewi, S. P., \& Haryani, A. (2017). Penerapan Kode Etik Jurnalistik Pada Penulisan Berita Ahok Terkait Pemilukada Dki Jakarta 2017 Dalam Surat Kabar Kompas. Epigram, 14(1), 77-81. https://doi.org/10.32722/epi.v14i1.961

Margianto, J. H., \& Saefullah, A. (2012). Media Online: Pembaca, Laba dan Etika. Jakarta: Aliansi Jurnalis Independen.

Miles, M., \& Huberman, A. (1992). Analisis Data Kualitatif. Depok: UI Pers.

Miller, J. M. (Ed.). (2009). 21st Century Criminology: a Refference Handbook. New York: SAGE Publications, Inc.

Pramesti, O. L. (2014). Penerapan Kode Etik di Kalangan Jurnalis. Jurnal ILMU KOMUNIKASI, 11(1), 81-92. https://doi.org/10.24002/jik.v11i1.386 
176 | Kajian Jurnalisme

Volume 04 Nomor 02 Tahun 2021

DOI: $10.24198 / \mathrm{jkj} . v 4 \mathrm{i} 2.29323$

Prisgunanto, I. (2017). Kode Etik Jurnalistik Di Kalangan Wartawan Media Massa Cetak Islam. Jurnal Komunikasi Global, 6(2), 185-199. Diakses dari http://www.jurnal.unsyiah.ac.id/ JKG/article/view/9329

Shoemaker, P. J., \& Reese, S. D. (1996). Mediating the Message: Theories of Influence on Mass Media Message. London: Longman Publisher.

Wahyudi, J. (1991). Komunikasi jurnalistik, pengetahuan praktis kewartawanan, surat kabar, majalah, radio \& televisi. Bandung: Alumni.

Yin, R. K. (1996). Studi Kasus Desain \& Metode. Jakarta: Raja Grafindo Persada. 